\title{
Praksa za delo v upravi Poročilo o projektu Fakultete za upravo
}

\author{
Astrid Prašnikar \\ astrid.prasnikar@fu.uni-lj.si
}

Obvezna praksa študentov po dosedanji ureditvi ni bila posebej vsebinsko opredeljena, zato se je velikokrat izvajala rutinsko, brez posebnih programov, ciljev in namena. $V$ letošnjem letu pa smo na Fakulteti za upravo $v$ Ljubljani pričeli z izvajanjem aktivnosti in postopkov, na podlagi katerih bomo vzpostavili nov koncept opravljanja študentske prakse $v$ okviru programa visokošolskega študija po bolonjski deklaraciji.

Pripravili smo že nov osnovni skelet projekta, tako vsebinsko kot metodološko. Strateški cilji, ki jih zasledujemo pri razvoju študentske prakse, izhajajo z vidika ciljev pedagoškega procesa, kjer je praksa dejavnik, ki zagotavlja pridobivanje uporabnih znanj diplomantov Fakultete za upravo. Praksa tudi usmerja razvoj bolonjskih študijskih programov, prispeva k razvoju upravne discipline, povečuje zaposlitvene možnosti diplomantov in povečuje mednarodno izmenjavo študentov ter diplomantov pri pridobivanju delovnih izkušenj. S prenovo načina izvajanja prakse študentov želimo doseči, da bi bila vsebina študijskega procesa usmerjena $v$ opredeljevanje in merjenje znanj diplomantov in njihove uspešnosti pri zaposlovanju $v$ upravi. Naš namen je tudi, da bi se programi predmetov izoblikovali in osredotočili na vsebine, pomembne za reševanje nalog in problemov $v$ upravi, in bi se $v$ pedagoški proces vključevali strokovnjaki iz prakse: neposredne (aktivne) in posredne (pasivne) prakse, da bi se povečala motivacija študentov za uspešnejše študijske rezultate in povečevala odgovornost do pridobivanja znanja in delovnega mesta ter da bi se med delodajalci diplomantov izboljšala razpoznavnost študentov Fakultete za upravo po njihovi prizadevnosti in odgovornosti. Vsebinske in organizacijske osnove za izvajanje prakse smo že vzpostavili v juniju 2006, še prej pa smo začeli z izvedbo projekta vključevati strokovnjake iz prakse.

Prakso smo smiselno $v$ vsebinskem smislu razdelili na naslednja osnovna področja: državna uprava, lokalna samouprava, druge osebe javnega prava in praksa $\vee$ mednarodnih institucijah. Občine bi $\vee$ okviru sodelovanja $\vee$ projektu 


\section{Astrid Prašnikar}

\section{Praksa za delo v upravi}

ponudile okolje, v katerem bi določeno število (nekaj deset) študentov, ki bodo izkazali ustrezno zavzetost, delovalo $v$ lokalnih skupnostih po sistemu aktivne prakse. To pomeni, da bi v času prakse (predvidoma 4-5 tednov, obdobje maj, junij, september) delali pri konkretnih nalogah in hkrati pridobili ustrezna znanja. Ker bi bila praksa povezana s konkretnimi nalogami, ki bi jih predlagala občina sama in bi te včasih tudi presegale zahtevnost in čas odmerjen za obvezno prakso, bi študentje $\vee$ nadaljevanju lahko rezultate prakse nadgradili $v$ diplomsko delo ali pa bi $v$ zvezi $s$ konkretnimi vprašanji celo izvedli skupaj $z$ mentorji na fakulteti posamezne projekte, za katere bi bil $\vee$ občini interes. Takšno sodelovanje bi lahko vodilo tudi do morebitne zaposlitve ali vsaj do evidenc, iz katerih bi v lokalnih skupnostih dobili pregled nad usposobljenostjo naših študentov, bodočih prosilcev zaposlitev, in posredno do večanja učinkovitosti občinskih uprav, kar je naš skupni interes in cilj. Konkretni projekti bi bili tudi za občine zanimivi in bi pripomogli k večji zainteresiranosti občin za obvezno prakso študentov.

Zamišljeni način izvajanja prakse pomeni hkrati tudi pripravljenost Fakultete za upravo, da prisluhne potrebam uprave kot bodočega delodajalca in vključuje javne uslužbence, ki bi prevzeli mentorstvo študentom, v pedagoško udejstvovanje in druge možnosti sodelovanja pri različnih področjih delovanja Fakultete za upravo ter $v$ prenos znanja iz tujine prek izmenjav Erasmus, programov Leonardo, raziskav, ipd.).

Za izvedbo projekta smo predvideli institucionalizacijo oblikovanja, izvajanja in evalvacije prakse na naslednjih ravneh: imenovanje posebnega organa predstavništva organizacij in imenovanje strokovnega tima. Predstavništvo organizacij, $v$ katerih se bo praksa opravljala in smo jih razvrstili v matrična štiri področja, bo imelo funkcijo vrhovnega projektnega sveta oz. krmilnega telesa na strateški ravni. Poslanstvo omenjenega telesa s skupno 16 člani (4 predstavniki državne uprave, 4 lokalne samouprave, 4 drugih oseb javnega prava in 4 predstavniki Fakultete za upravo) je sprejem načelnih stališč o vsebini študentske prakse, sprejem norm in standardov glede načina opravljanja študentske prakse ter verifikacija formalnih razmerij med fakulteto, študenti in organizacijami, kjer se bo praksa izvajala (vključitev praktikantov $\vee$ kadrovski načrt, določitev tipske pogodbe o praksi, dogovor o nagrajevanju mentorjev študentov $\checkmark$ organih in podobno). Že takoj ob uvedbi projekta je bil imenovan strokovni tim s štirimi področnimi projektnimi timi. Za izvedbo projekta je bila imenovana projektna skupina v sestavi: prof. dr. Srečko Devjak - vodja projekta, dr. Polona Kovač, dr. Primož Pevcin, Stanka Primc,dr. Janez Stare, mag. Nina Tomaževič, vsi tudi kot vodje projektnih timov za posamezna področja, Astrid Prašnikar - za področje lokalne samouprave in predstavnik študentov. 
Od lokalnih skupnosti pričakujemo, da svojega predstavnika $\vee$ predstavništvo organizacij predlagajo: obe združenji občin, združenje tajnikov ter minister za lokalno samoupravo in regionalni razvoj. Sistem študentske prakse bi namreč že od začetka želeli zasnovati na strateški in na operativni ravni kot partnersko sodelovanje. Velja poudariti, da gre za strateško telo, v katerem naj bi sodelovali uradniki na najvišjih položajih, ki strokovno poznajo področje dela.

Vsebinsko bomo prakso oblikovali v okviru tem praktičnega usposabljanja, ki jih bodo študentje izvedli pri opravljanju prakse. Teme bodo opredeljene tako, da bodo $\vee$ njih vključene vsebine, ki jih bodo študentje osvojili $\vee$ okviru vpisanega programa študijskih predmetov. Teme bodo problemsko opredeljene glede na mesto oz. organizacijo, kjer bo študent lahko opravljal prakso.

Študent bo opravljal prakso ob mentorju v organizaciji, ki bo vnaprej seznanjen s terminom, temo in podatki o študentu. Mentor bo ocenjeval delo študenta in ugotovil znanja in druge rezultate prakse, ki jih bo posredoval Fakulteti za upravo. Mentor se bo tudi udeležil uvodnega usposabljanja, aktualnih seminarjev in drugih usposabljanj v organizaciji Fakultete za upravo, povezanih s kakovostnim opravljanjem mentorstva.

Začetni seznam je projektna skupina Fakultete za upravo že pripravila. Na osnovi tega seznama so dodali teme še člani strokovnih timov. $\vee$ nadaljevanju pa pričakujemo tudi predloge tem od organizacij, občin neposredno. Predlagani seznam tem je za posamezne primere opremljen s kratkimi navodili (strokovnimi, organizacijskimi, metodološkimi) in z zahtevami za teme praktičnega usposabljanja ter z vzorčnim primerom.

Projektna skupina je predstavništvu organizacij že prestavila osnutke dokumentov: dogovora o sodelovanju - fakulteta z občino, pogodbe med občino, fakulteto in študentom, programa učne vsebine, ocenjevalnega lista, evidence razporejanja praktikantov in predloge izbranih tem z vzorčnimi primeri obdelanih konkretnih tem.

Da bi zastavljeni projekt prakse študentov zaživel v skladu s pripravljenimi izhodišči, nameni in cilji, bo odločujoče dobro sodelovanje z organizacijamiobčinami in njihovimi predstavniki v organih oz. delovnih telesih projekta. Zato bomo veseli vsake pripombe ali predloga in predvsem hvaležni za pripravljenost posamezne občine kot tudi združenj občin in tajnikov, da sodelujejo $v$ projektu. 